$14^{\text {th }}$ Conf. Agric. Develop. Res., Fac. of Agric., Ain Shams Univ.,

March, 2019, Cairo, Egypt

Special Issue, 27(1), 51 - 59, 2019

Website: http://strategy-plan.asu.edu.eg/AUJASCI/

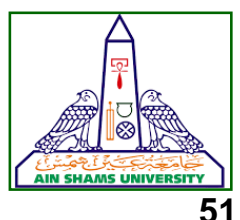

\title{
BIOCHAR AS A STRATEGY TO ENHANCE GROWTH AND YIELD OF WHEAT PLANT EXPOSED TO DROUGHT CONDITIONS
}

\author{
Wesam Mansour , Salim B.B.M., Hussin S. and Abd El-Rassoul M. \\ Botany Dept., Fac. of Agric., Ain Shams Univ., P.O. Box 68, Hadyek Shoubra 11241, \\ Cairo, Egypt
}

*Corresponding author: wesam.mansour@agr.asu.edu.eg

Received 23 September, 2018, Accepted 9 October, 2018

\begin{abstract}
Drought has become major environmental constraint to the crops productivity and the sustainability of agriculture. Recently, using biochar (BC) as a soil conditioner has aroused much interest and proved to be an effective tool for improving soil properties and crops growth and yield. Therefore, a pot trial was conducted using wheat plant (Triticum aestivum L.) with three water regimes $(60,30$ and $15 \%$ of water holding capacity(WHC)) and three rates of biochar $(0,2 \%$, and $5 \%)$ to investigate the impact of biochar on growth and yield components. The results showed that WHC enhanced in the presence of $\mathrm{BC}$ leading to improving the availability of water to wheat plants grown in BC-treated soil. Plants grown in BC-amended soil had higher growth and plant biomass, net assimilation rates than those in un-amended soil. Biochar addition positively affected wheat growth parameters including increases in leaf area, number of leaves per plant, tillers number per plant, height of plant as well as shoot to root fresh weight ratio. Particularly interesting is the improvements in yield attributes. These results led us to conclude that the application of black carbon would enhance the growth and yield of crops under insufficient water supply. On other hand, biochar can be considered an effective tool for sustainable agriculture and hence mitigating the injurious effects of drought conditions on plants.
\end{abstract}

Key words: Drought, Biochar, Wheat (Triticum aestivum L.), soil modification

\section{INTRODUCTION}

Excessive concerns about Global warming as it triggers more extreme events, such as heat and drought stress which threaten the growth and yield of crops (Zinta et al 2014). Drought is considered to be one of the hazardous disasters in the world which affected negatively on crops productivity and caused considerable economic losses (Mishra and Singh 2010; Piao 2010 and Lobell \& CostaRoberts 2011). Drought limits plant growth and field crop production more than any other environmental stresses because of the role of water on plant growth, physiological processes especially photosynthetic performance (Baronti et al 2014 and Paneque et al 2016).

Wheat (Triticum aestivum L.) is widely cultivated cereal crop ranked after maize and rice. Annually, the world wheat production is around 650 million tons (FAO, 2012). However, approximately $70 \%$ of the cultivated area is situated in areas classified as arid and semi-arid and exposed to drought stress (Zhang and Zheng 2011). So, about $50-90 \%$ of Wheat productivity decreased affected by water deficit and around $600,000 \mathrm{~km}^{2}$ in developing world (Skovmand et al 2001).

Direct incorporation of carbon in stable forms to soils has been considered an interesting option to sequester carbon in soils. The positivity effect of soil organic carbon (SOC) for sustainable agriculture is related to enhanced soil structure, higher retention of nutrients and water, a good habitat for soil organisms (Lal 2009 and Lorenz et al 2007).

In recent years, a new green biofuel produced from the in-complete combustion of biomass called biochar has been increasingly discussed as an alternative to organic amendments for sequester- 
ing carbon into soils and also mitigating soil properties (Glaser et al 2002 and Lehmann 2006).

Biochar applications is attracting great interest as a strategy proposed for both improving crop productivity and mitigating global warming which can persist in the soil from 1000 to 10,000 years (Atkinson et al 2010; Stavi \& Lal 2013 and Lehmann et al 2006).

This idea originates in the 19th century when dark earth (Terra preta) has been discovered in the Amazon region (Glaser et al 2001 and Marris 2006). Terra preta (TP) is a fertile soil in an infertile containing high concentration of nutrients, soil organic matter (SOM) and consequently several crops production per year without extra fertilization (Lehmann et al 2003 and Glaser 2007).

In our work, we hypothesize that using biochar as a soil amendment will improve plant performance under adequate and insufficient water supply resulting in higher growth and yield of wheat plants. It was also desired to elucidate that the ability of biochar to enhance plant performance as it will not only mitigate soil fertility but also improve soil water retention leading to ameliorate of plant water statue. Also, Long-term studies are needed to understand biochar's effect on plant physiology and the mechanisms using biochar can be applied in a wide range of agricultural conditions for improving crop production.

\section{MATERIALS AND METHODS}

The present study was carried out at the greenhouse of the Agricultural Botany Department, Faculty of Agriculture, Ain Shams University, Qalyubia Governorate, Egypt $\left(30^{\circ} 06^{\prime} 42^{\prime \prime} \mathrm{N} 31^{\circ}\right.$ $14^{\prime} 46^{\prime \prime} \mathrm{E}$ ). Pot experiments (two successive agricultural seasons) were conducted during 2014 and 2015 to investigate the influence of different biochar (locally-produced) soil application rates $(0,2$ and $5 \%$ ) on the growth, development and productivity of wheat plants under different water regimes (60, 30 and $15 \%$ WHC).

\section{Biochar preparation and soil mixtures}

Biochar used in the present study was produced using a locally manufactured pyrolytic equipment based on the Anila Stove design (Iliffe 2009). Feedstock used for biochar production was different biomass that commonly found in agricultural west of the Faculty of Agriculture. Biochar was generated through a slow pyrolysis process at a relatively range temperature between 350 and $550^{\circ} \mathrm{C}$.

\section{Experimental setup}

During the preparation of soil mixtures, nitrogen $\left(\mathbf{N H}_{4} \mathbf{N O}_{3}\right)$ phosphorus $\left(\mathbf{P}_{2} \mathbf{O}_{5}\right)$ and potassium $\left(\mathbf{K}_{2} \mathbf{S O}_{4}\right)$ were added to the soil according to the recommendation of (El-Fouly et al 2011). The substrate mixtures were then backed in black plastic pots $(30 \mathrm{~cm}$ inner diameter and $40 \mathrm{~cm}$ height, with 5 drainage holes at the bottom), $10 \mathrm{Kg}$ each pot. Accordingly, there were three groups of biochar treatments $(0,2$ and $5 \% \mathrm{BC})$, each of $30 \mathrm{ex}$ perimental pots.

Wheat (Triticum aestivum) grains of the cultivar Giza 168, known for its drought resistance under Egyptian conditions, was kindly provided by the Agriculture Research Center (ARC), Cairo, Egypt. The pots were kept in an open field greenhouse (wire house) under ambient conditions with temperatures of $20 \pm 3^{\circ} \mathrm{C}$ daytime and $14 \pm 3.5^{\circ} \mathrm{C}$ night time and a photoperiod of $10 / 14 \mathrm{~h}$. The relative humidity was in the range of $60-70 \%$, while the photosynthetic photon flux density ranged between 1500 and $2000 \mu \mathrm{mol} \mathrm{m} \mathrm{m}^{-2} \mathrm{~s}^{-1}$. The plants were then manually regularly irrigated with nutrient solution modified Hoagland and Arnon (1950) and the water content of the soil was maintained at $60-70$ $\%$ of the soil water holding capacity.

Drought stress treatment was initiated on 12 December by withholding watering to reach a soil water holding capacity of $60-70 \%$ for the first group (Ctr.), $30-40 \%$ for the second group (moderate drought; MD), and to $15-20 \%$ for the third group (severe drought; SD). For severe drought (SD) treatment, water supply was reduced until temporary wilting symptoms became visible on the plants. For all water treatments, soil moisture was maintained by daily adjustment using a digital balance to the desired target weight.

\section{Harvest procedure and agronomic traits}

For the vegetative samples, plants of three randomly selected pots (replicates) from each treatment were individually harvested and immediately divided into roots (R), stem (S) and leaves (L), after measuring their heights (Ph). Thereafter, the fresh weight of all plant organs was captured. The number of tillers, and leaves per plant and leaf area $\mathrm{cm}^{2}$ per leaf were also determined. Additionally, the ratio between shoot and root fresh weight was calculated. 
Representative samples (approx. 2-3 g) of all plant organs were also dried at $70{ }^{\circ} \mathrm{C}$ in forced air driven oven for $72 \mathrm{~h}$ or until constant weight was reached.

For plants grown to maturity (yield samples), the spikes of each experimental pot (three replicates each treatment) were gently separated from the stems. The number, length and weight of spikes per plant were recorded, and the wheat grains were separated from the spikes by hand. The grains yield per plant as well as the weight of 100 grain was also determined.

\section{Statistical analysis}

Data sets of each growing seasons were separately statistically analyzed by one-way analysis of variance (ANOVA) using SPSS for Windows statistical data analysis package (SPSS Inc., 2002, release 16, Chicago, IL, USA). The differences between means $(P \leq 0.05)$ were determined by Duncan's multiple range tests.

\section{RESULTS}

Both drought stress and biochar applications significantly altered wheat growth and development (in terms of biomass accumulation).
Biochar soil amendment treatments significantly $(\mathrm{P} \leq 0.05)$ increased the plant fresh weight in a dose-additive pattern (Fig. 1). Under adequate irrigation, plant biomass was enhanced by about $183 \%$ and $100 \%$ for plants treated with $2 \%$ and $5 \%$ BC, respectively, compared untreated controls (Fig. 1). The same trend was also observed for plants exposed to moderate drought stress conditions, where BC applications at $2 \%$ and $5 \%$ led to increase of plant biomass by 4.0 and 2.2 folds, respectively, in compared to the respective controls (Fig. 1).

However, this growth promoting effect was less obvious under severe drought stress, as BC applied at $2 \%$ and $5 \%$ resulted in increase of plant biomass reached to $80.4 \%$ and $58.4 \%$, respectively, compared to un-amended controls by biochar (Fig. 1.).

Data presented in Table (2) clearly show that both drought stress and biochar treatments significantly altered all yield components. Compared with the corresponding controls, BC applied at $2 \%$ and $5 \%$ caused significant $(P \leq 0.05)$ increases in spikes number per plant (SNPP), spike length (SL), average spike weight (ASW) and thus the 100 grain weight under both well-watered and water deficit treatments.

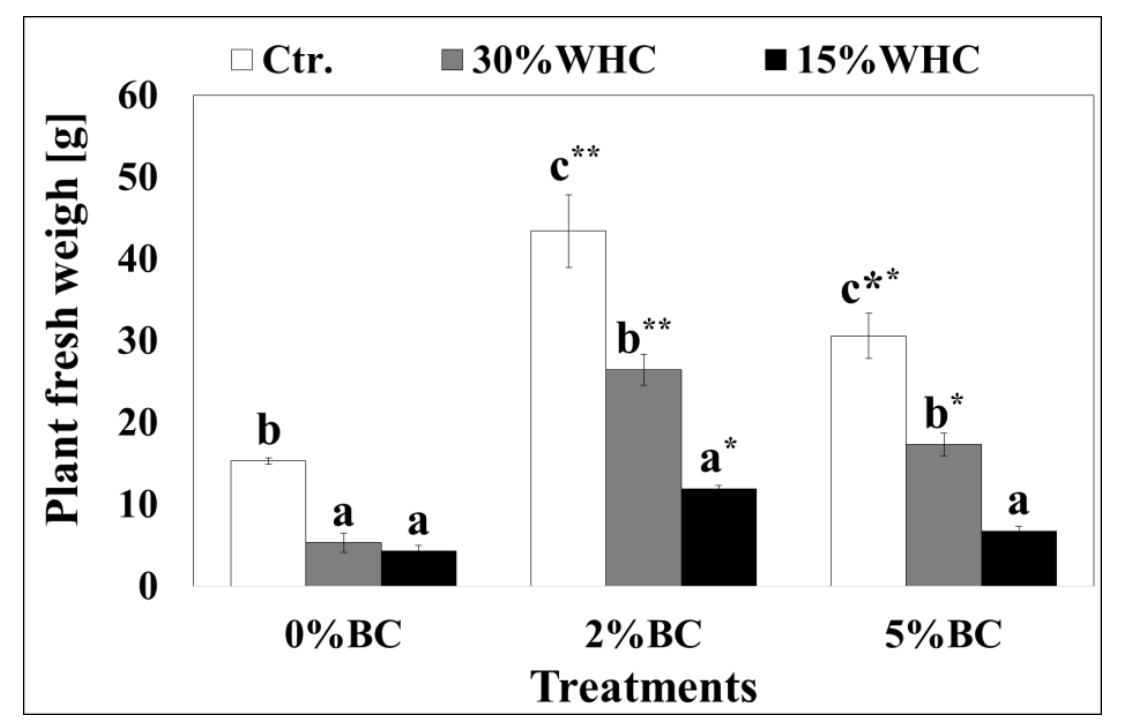

Fig. 1. Influence of different soil water content $(\mathrm{WHC})$ on the plant biomass accumulation at various levels of biochar $(\mathrm{BC})$ soil applications. Each columns represents the mean of three replicates $\pm \mathrm{SD}$. Significant differences $(P \leq 0.05)$ between drought treatments (within one biochar treatment) are indicated by different letters, while significant differences between the biochar treatments (within one drought treatment) are indicated by asterisk. 
Table 1. Effect of different soil water content (WHC) and various levels of biochar (BC) soil applications on the plant height, number of tillers per plant, leaf number per plant, leaf area per leaf, leaf mass to area ratio (LMA) and shoot to root fresh weight ratio of wheat plants.

\begin{tabular}{|c|c|c|c|c|c|c|c|c|c|}
\hline \multirow[t]{2}{*}{ Parameters } & \multicolumn{3}{|c|}{$0 \% \mathrm{BC}$} & \multicolumn{3}{|c|}{$2 \% \mathrm{BC}$} & \multicolumn{3}{|c|}{$5 \% \mathrm{BC}$} \\
\hline & Ctr. & $30 \% W H C$ & $15 \%$ WHC & Ctr. & $30 \% W H C$ & $15 \% \mathrm{WHC}$ & Ctr. & $30 \% W H C$ & $15 \%$ WHC \\
\hline \multirow[t]{2}{*}{ Plant height $[\mathrm{cm}]$} & $71.500^{\mathrm{a}}$ & $81.500^{b}$ & $86.000^{b}$ & $111.00^{\mathrm{a}^{*}}$ & $107.00^{\mathrm{a}^{*}}$ & $106.000^{\mathrm{a}^{* *}}$ & $106.000^{\mathrm{a}^{*}}$ & $98.000^{\mathrm{a}^{*}}$ & $94.000^{\mathrm{a}^{*}}$ \\
\hline & \pm 6.364 & \pm 2.121 & \pm 4.243 & \pm 2.000 & \pm 0.000 & \pm 5.657 & \pm 6.245 & \pm 1.414 & \pm 0.000 \\
\hline \multirow{2}{*}{$\begin{array}{c}\text { Number of till- } \\
\text { ers/plant }\end{array}$} & $3.500^{b}$ & $1.185^{\mathrm{a}}$ & $0.940^{a}$ & $5.089^{b^{*}}$ & $3.000^{\mathrm{a}^{*}}$ & $2.733^{\mathrm{a}^{*}}$ & $5.200^{b^{*}}$ & $3.267^{\mathrm{a}^{*}}$ & $2.150^{\mathrm{a}^{*}}$ \\
\hline & \pm 0.300 & \pm 0.170 & \pm 0.343 & \pm 0.619 & \pm 0.200 & \pm 0.733 & \pm 1.058 & \pm 0.115 & \pm 0.507 \\
\hline \multirow{2}{*}{$\begin{array}{c}\text { Leaves num- } \\
\text { ber/plant }\end{array}$} & $12.667^{c}$ & $5.319^{b}$ & $3.250^{\mathrm{a}^{*}}$ & $14.933^{\mathrm{c}^{*}}$ & $10.756^{b^{*}}$ & $4.700^{\mathrm{a}^{* *}}$ & $18.333^{\mathrm{c}^{* *}}$ & $11.733^{b^{*}}$ & $4.183^{\mathrm{a}}$ \\
\hline & \pm 0.702 & \pm 0.970 & \pm 0.354 & \pm 1.286 & \pm 2.168 & \pm 0.141 & \pm 2.532 & \pm 1.514 & \pm 0.708 \\
\hline \multirow{2}{*}{$\begin{array}{c}\text { Leaf area/leaf } \\
{[\mathrm{cm}]}\end{array}$} & $26.486^{b}$ & $16.103^{\mathrm{a}}$ & $12.056^{\mathrm{a}}$ & $37.227^{\mathrm{c}^{* *}}$ & $25.926^{b^{*}}$ & $19.131^{\mathrm{a}}$ & $31.919^{b^{*}}$ & $19.933^{\mathrm{a}}$ & $16.555^{\mathrm{a}}$ \\
\hline & \pm 0.330 & \pm 2.671 & \pm 1.255 & \pm 1.780 & \pm 0.198 & \pm 4.062 & \pm 4.323 & \pm 0.916 & \pm 2.730 \\
\hline \multirow{2}{*}{$\begin{array}{l}\text { Leaf mass: area } \\
\text { ratio [LMA] }\end{array}$} & $18.43^{b^{*}}$ & $14.713^{\mathrm{a}}$ & $13.902^{\mathrm{a}}$ & $16.147^{\mathrm{ab}}$ & $15.214^{\mathrm{a}}$ & $16.203^{b^{* *}}$ & $16.818^{b}$ & $16.277^{b}$ & $14.251^{\mathrm{a}^{*}}$ \\
\hline & \pm 0.087 & \pm 1.731 & \pm 1.427 & \pm 0.737 & \pm 0.511 & \pm 0.010 & \pm 0.561 & \pm 0.805 & \pm 1.109 \\
\hline \multirow{2}{*}{$\begin{array}{c}\text { Shoot: root fresh } \\
\text { weight ratio }\end{array}$} & $2.588^{\mathrm{a}}$ & $3.669^{\mathrm{ab}}$ & $5.208^{b}$ & $7.691^{\mathrm{a}^{*}}$ & $6.732^{\mathrm{a}^{*}}$ & $5.199^{\mathrm{a}}$ & $6.663^{\mathrm{a}^{*}}$ & $5.775^{b^{4 *}}$ & $5.418^{\mathrm{a}}$ \\
\hline & \pm 0.011 & \pm 0.815 & \pm 1.158 & \pm 1.198 & \pm 1.789 & \pm 0.294 & \pm 1.592 & \pm 1.607 & \pm 1.150 \\
\hline
\end{tabular}

Values are the mean of three replicates \pm SD. Significant differences $(P \leq 0.05)$ between drought treatments (within one biochar treatment) are indicated by different letters, while significant differences between the biochar treatments (within one drought treatment) are indicated by asterisk.

Table 2. Influence of different soil water regime (WHC) and various levels of biochar (BC) soil applications on the spike number per plant, spike length, spike weight pare spike, grain yield per plant and weight of 100 grains of wheat plants.

\begin{tabular}{|c|c|c|c|c|c|c|c|c|c|}
\hline \multirow{2}{*}{ Traits } & \multicolumn{3}{|c|}{$0 \% \mathrm{BC}$} & \multicolumn{3}{c|}{$2 \% \mathrm{BC}$} & \multicolumn{3}{c|}{$5 \% \mathrm{BC}$} \\
\cline { 2 - 10 } & Ctr. & $30 \% \mathrm{WHC}$ & $15 \% \mathrm{WHC}$ & Ctr. & $30 \% \mathrm{WHC}$ & $15 \% \mathrm{WHC}$ & Ctr. & $30 \% \mathrm{WHC}$ & $15 \% \mathrm{WHC}$ \\
\hline Spike num- & $1.583^{\mathrm{a}}$ & $1.000^{\mathrm{b}}$ & $0.821^{\mathrm{b}}$ & $2.911^{\mathrm{a}^{*}}$ & $1.800^{\mathrm{a}^{*}}$ & $1.333^{\mathrm{c}^{*}}$ & $3.800^{\mathrm{a}^{* *}}$ & $2.400^{\mathrm{b}^{* *}}$ & $1.894^{\mathrm{c}^{* *}}$ \\
ber/plant & \pm 0.176 & \pm 0.333 & \pm 0.156 & \pm 0.500 & \pm 0.200 & \pm 0.306 & \pm 0.529 & \pm 0.400 & \pm 0.387 \\
\hline Spike length & $7.726^{\mathrm{b}^{*}}$ & $7.214^{\mathrm{b}^{*}}$ & $5.667^{\mathrm{a}^{*}}$ & $8.594^{\mathrm{b}^{*}}$ & $9.236^{\mathrm{b}^{*}}$ & $6.159^{\mathrm{a}^{*}}$ & $9.146^{\mathrm{b}}$ & $8.819^{\mathrm{b}}$ & $7.952^{\mathrm{a}}$ \\
[cm] & \pm 0.426 & \pm 0.639 & \pm 1.137 & \pm 0.156 & \pm 0.550 & \pm 0.571 & \pm 0.235 & \pm 0.341 & \pm 0.393 \\
\hline Average spike & $0.485^{\mathrm{b}}$ & $0.532^{\mathrm{b}^{*}}$ & $0.374^{\mathrm{a}^{*}}$ & $0.956^{\mathrm{b}}$ & $0.970^{\mathrm{b}^{*}}$ & $0.532^{\mathrm{a}^{* *}}$ & $0.960^{\mathrm{a}}$ & $1.213^{\mathrm{b}}$ & $0.877^{\mathrm{a}}$ \\
weight [g] & \pm 0.073 & \pm 0.061 & \pm 0.026 & \pm 0.003 & \pm 0.112 & \pm 0.132 & \pm 0.105 & \pm 0.214 & \pm 0.005 \\
\hline Grains & 12.715 & $3.783^{\mathrm{b}}$ & $0.423^{\mathrm{a}}$ & $30.147^{\mathrm{c}^{*}}$ & $15.777^{\mathrm{b}^{*}}$ & $3.293^{\mathrm{a}^{*}}$ & $26.330^{\mathrm{c}^{*}}$ & $15.455^{\mathrm{b}^{*}}$ & $1.122^{\mathrm{a}}$ \\
yield/plant [g] & \pm 1.072 & \pm 0.781 & \pm 0.157 & \pm 2.538 & \pm 1.257 & \pm 0.753 & \pm 0.244 & \pm 4.379 & \pm 0.088 \\
\hline Weight of 100 & $2.266^{\mathrm{b}}$ & $2.022^{\mathrm{b}}$ & $0.514^{\mathrm{a}}$ & $3.024^{\mathrm{ab}^{*}}$ & $3.313^{\mathrm{b}^{*}}$ & $2.674^{\mathrm{a}^{* *}}$ & $3.065^{\mathrm{b}^{*}}$ & $3.231^{\mathrm{b}^{*}}$ & $1.122^{\mathrm{a}^{*}}$ \\
grains [g] & \pm 0.188 & \pm 0.520 & \pm 0.002 & \pm 0.226 & \pm 0.292 & \pm 0.200 & \pm 0.302 & \pm 0.134 & \pm 0.088 \\
\hline
\end{tabular}

Values are the mean of three replicates $\pm S D$. Significant differences $(P \leq 0.05)$ between drought treatments (within one biochar treatment) are indicated by different letters, while significant differences between the biochar treatments (within one drought treatment) are indicated by asterisk. 
Overall, the BC applied either at $2 \%$ or $5 \%$ had improved grains yield per plant (GYPP), regardless of water treatments. Under adequate irrigation, GYPP was increase by about $137.0 \%$ and $107.1 \%$ in plants amended with biochar at $2 \%$ and $5 \%$, respectively, as compared to non $\mathbf{B C}$ treatment (Fig. 2). The interactive effect of drought and BC treatments was highly significant, as BC applica- tions at 2 and 5\% increased the GYPP around $317.1 \%$ and $308.5 \%$, respectively, for plants exposed to moderate water stress. Under severe drought stress conditions, BC treatments at 2 and $5 \%$ raised by 6.7 and 1.6 folds increases in the GYPP, respectively, relative to the respective controls (Fig. 2).

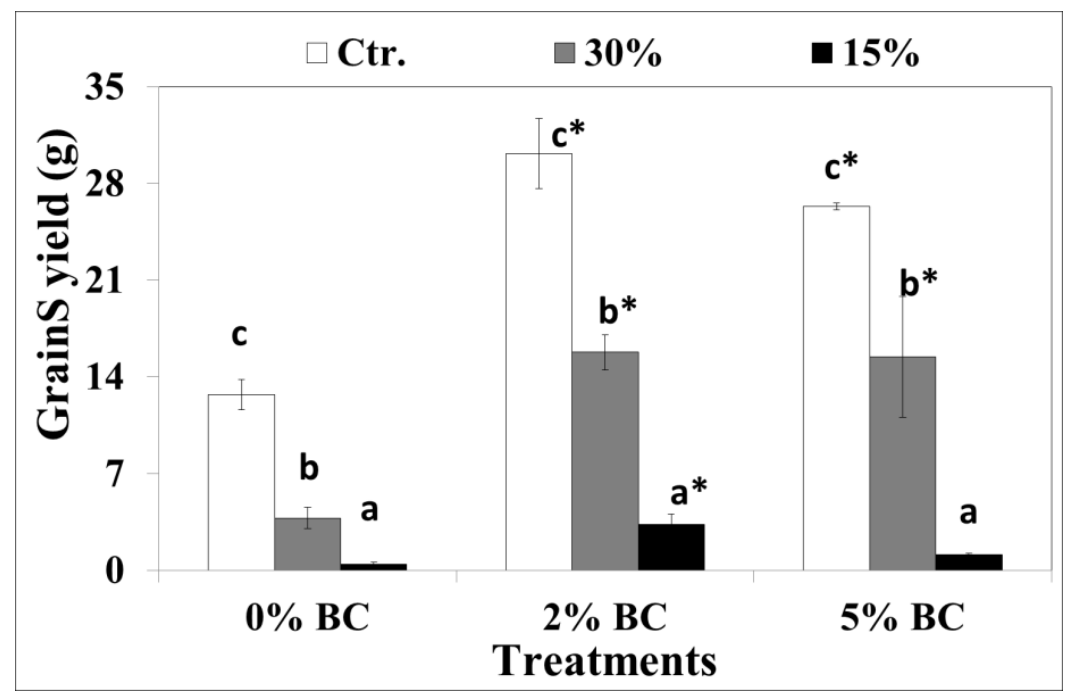

Fig. 2. Influence of different soil water content (WHC) on grain yield per plant at various levels of biochar $(B C)$ soil applications. Each columns represents the mean of three replicates \pm SD. Significant differences $(P \leq 0.05)$ between drought treatments (within one biochar treatment) are indicated by different letters, while significant differences between the biochar treatments (within one drought treatment) are indicated by asterisk.

\section{DISCUSSION}

Drought stress is the most important abiotic factor limiting growth and yield. Drought stress conditions reduced nutrients availability and nutrients uptake by the roots as a result of the reduction of nutrients diffusion rate from the soil to roots surfaces. Decreasing nutrients absorption is considered the most important limiting factors to plant growth, development and lead to dramatic annual yield losses in different crops (Alia et al 2007; Manivannan et al 2008; Li et al 2009; Farooq et al 2009 and Fathi and Tari 2016).

Vegetative growth such as tillers number, flag leaf area, leaf area/plant, number of leaves/plant, height of plant, shoots dry weight/plant, and roots dry weight/plant was negatively impacted by insufficient water supply treatments as compared with ordinary water supply. Drought stress led to losses in water content of plant tissues causing reduction in turgor pressure of cells thereby cell division and enlargement were inhibited. Therefore, water stress is considered to be constrain to elongation of internode as well leaf expansion causing significantly reduction of plant growth and the accumulated dry mass and hence decreasing in plant productivity (Alia et al 2007 and Maria et al 2008).

Dramatic yield losses in crops exposed to drought stress conditions through its different growth stages. Expose plants to lower water supply during the period from the seedling to maturity impacted negatively on all yield components, especially fertile ears number per unit area and head grains number reduced by $60 \%$ and $48 \%$, respectively (Giunta et al 1993).

Richards et al (2001) drought stress decreased the number and weight of grains due to disrupted flowing photosynthesis products and transfer from source (leaves) to sink (grains). Also, water deficit stress cause pollen sterility, grains loss and accumulation of abscisic acid in spikes ( $\mathbf{J i}$ et al 2010). 
Adding biochar to soils can play important roles to improve the physical, chemical, biological characteristics of the cultivated soils, which had positively reflex on enhancing the growth, development and productivity of various plants. Of which, water holding capacity (WHC), soil fertility (SF) and Carbon reservation benefit to produce increase crop yields (Glaser et al 2002; Ali et al 2017; Atkinson et al 2010 and Schulz \& Glaser 2012).

As well, improving soil fertility by biochar applications comes through its direct and indirect effects. The direct effect is due to the nutrients presented on surfaces of BC particles in mineral forms. In addition, BC improved the physical properties of the soil especially the soil water holding capacity and reduced soil compaction whereas those favorable changes leading to improving root proliferation and promoting crop growth and development. As well, BC plays an important role on nutrients availability for plants and looks like matrix of ion exchange catching higher amount of cations $\left(\mathrm{K}^{+}, \mathrm{Ca}^{++}\right.$and $\mathbf{M g}^{++}$(Glaser et al 2002; Lehmann et al 2005; Yamato et al 2006; Laird et al 2010 and Olmo et al 2014).

Stimulation growth as well as productivity of plants under biochar applications may be due to increase cation exchange capacity (CEC), microbial activity in the soils, higher levels of nutrients, particularly $\mathbf{N}, \mathbf{P}, \mathbf{K}, \mathbf{C a}$ and $\mathbf{M g}$ had been become available to uptake by plants (Atkinson et al 2010; Biedermann \& Harpole 2013; Zhao et al 2014 and Silva et al 2017). Also, biochar ameliorates the deleterious effects of drought stress on growth development, and yield of plant by increasing nutrients uptake, enhancing photosynthesis, and modified gas exchange characteristics as well (Ali et al 2017).

The different responses to $\mathrm{BC}$ treatment reflex on the yield for numerous crop varieties. Positivity or negativity of $\mathrm{BC}$ treatment impacts might depend on the biochar type, amounts and properties of the biochar used, soil characteristics, plant varieties and climatically conditions (Alburquerque et al 2013 and 2014; Akhtar and Sarmah 2018). For instance, grains yield of wheat plant increased by $18 \%$ when using oil mallee biochar (Solaiman et al 2010).

\section{CONCLUSION}

Drought negatively influenced growth and development of wheat leading to consequently decrease the grain yield. Using biochar (BC) as a soil conditioner recently proved to be an effective tool for improving soil properties and crops growth and finally enhanced yield of crops. our results confirmed that biochar applications improved wheat growth and thus yield and these improvements may be explained by via several mechanisms: (a) a better water holding capacity (WHC) caused by the porous of $\mathbf{B C}$ and the increased root biomass led to enhance the plant water status (b) both of charged surfaces of BC particles and also the porosity of $\mathbf{B C}$ were responsible for the higher nutrient retention of amended-soil and subsequently more availability of nutrients to biochar treated plants than non-treated ones (c) finally, the enhanced water statue and nutrients availability resulted in higher shoot system and consequently larger photosynthetic net assimilation leading to increased wheat yield. Therefore, it can be claimed that biochar incorporation into soils is a novel approach for improving plant growth and increasing crop productivity under critical drought stress conditions.

Future work is anticipated on the stability of biochar in the soils and its impact on plant physiology under stress conditions.

\section{REFERENCE}

Akhtar A. and Sarmah A.K. 2018. Novel biocharconcrete composites: manufacturing, characterization and evaluation of the mechanical properties. Science of the Total Environment. 616, 408-416.

Alburquerque J.A., Calero J.M., Barrón V., Torrent J., del Campillo M.C., Gallardo A. and Villar R. 2014. Effects of biochars produced from different feedstocks on soil properties and sunflower growth. Journal of Plant Nutrition and Soil Science. 177, 16-25.

Alburquerque J.A., Salazar P., Barrón V., Torrent J., del Campillo M.D.C., Gallardo A., and Villar R. 2013. Enhanced wheat yield by biochar addition under different mineral fertilization levels. Agronomy for Sustainable Development. 33, 475-484.

Alia A.M. and Namich 2007. Response of cotton cultivar giza 80 to application of glycine betaine under drought conditions. Minufiya J. Agric. 32, 1637-1651

Ali S., Rizwan M., Qayyum M.F., Ok Y.S., Ibrahim M., Riaz M., Arif M.S., Hafeez F., AlWabel M.I. and Shahzad A.N. 2017. Biochar soil amendment on alleviation of drought and salt stress in plants: a critical review. 
Environmental Science and Pollution Research. 24, 12700-12712.

Atkinson C.J., Fitzgerald J.D. and Hipps N.A. 2010. Potential mechanisms for achieving agricultural benefits from biochar application to temperate soils: a review. Plant and Soil. 337, 1-18.

Baronti S., Vaccari F.P., Miglietta F., Calzolari C., Lugato E., Orlandini S., Pini R., Zulian C., and Genesio L. 2014. Impact of biochar application on plant water relations in Vitis vinifera (L.). European Journal of Agronomy. 53, 38-44.

Biederman L.A. and Harpole W.S. 2013. Biochar and its effects on plant productivity and nutrient cycling: a meta-analysis. GCB Bioenergy. 5, 202-214.

El-Fouly M.M., Mobarak Z.M., and Salama Z.A. 2011. Micronutrients (Fe, Mn, Zn) foliar spray for increasing salinity tolerance in wheat Triticum aestivum L. African Journal of Plant Science. 5, 314-322.

Farooq M., Wahid A., Kobayashi N., Fujita D., and Basra S. 2009. Plant drought stress: effects, mechanisms and management. Sustainable Agriculture,PP. 153-188.

Fathi A. and Tari D.B. 2016. Effect of drought stress and its mechanism in plants. International Journal of Life Sciences. 10, 16.

Giunta F., Motzo R. and Deidda M. 1993. Effect of drought on yield and yield components of durum wheat and triticale in a Mediterranean environment. Field Crops Research. 33, 399409.

Glaser B. 2007. Prehistorically modified soils of central Amazonia: a model for sustainable agriculture in the twenty-first century. Philosophical Transactions of the Royal Society of London B: Biological Sciences. 362, 187-196.

Glaser B., Haumaier L., Guggenberger G., and Zech W. 2001. The 'Terra Preta' phenomenon: a model for sustainable agriculture in the humid tropics. Naturwissenschaften. 88, 37-41.

Glaser B., Lehmann J. and Zech W. 2002. Ameliorating physical and chemical properties of highly weathered soils in the tropics with charcoal-a review. Biology and Fertility of Soils. 35, 219-230.

Hoagland D.R. and Arnon D.I. 1950. The waterculture method for growing plants without soil. Circular. California Agricultural Experiment Station. 347, 23-32.
Iqbal S. 2009. Physiology of wheat (triticum aestivum I.) accessions and the role of phytohormones under water stress. Ph.D. Thesis, Fac. of Biological Sci., Quaid-i-azam Univ., Islamabad,PP. 83-154.

Ji X., Shiran B., Wan J., Lewis D.C., Jenkins C. L., Condon A.G., Richards R.A., and Dolferus R. 2010. Importance of pre-anthesis anther sink strength for maintenance of grain number during reproductive stage water stress in wheat. Plant, Cell \& Environment. 33, 926942.

Laird D.A., Fleming P., Davis D.D., Horton R., Wang B. and Karlen D.L. 2010. Impact of biochar amendments on the quality of a typical Midwestern agricultural soil. Geoderma. 158, 443-449.

Lal R. 2009. Soils and food sufficiency: A review. In "Sustainable Agriculture",PP. 25-49.

Lehmann J., da Silva J.P., Steiner C., Nehls T., Zech W. and Glaser B. 2003. Nutrient availability and leaching in an archaeological Anthrosol and a Ferralsol of the Central Amazon basin: fertilizer, manure and charcoal amendments. Plant and Soil. 249, 343-357.

Lehmann J., Gaunt J. and Rondon M. 2006. Biochar sequestration in terrestrial ecosystems-a review. Mitigation and Adaptation Strategies for Global Change. 11, 403-427.

Lehmann J., Liang B., Solomon D., Lerotic M., Luizão F., Kinyangi J., Schäfer T., Wirick S. and Jacobsen C. 2005. Near-edge X-ray absorption fine structure (NEXAFS) spectroscopy for mapping nano-scale distribution of organic carbon forms in soil: Application to black carbon particles. Global Biogeochemical Cycles 19,1-12.

Li Q., Xu C., Liang W., Zhong S., Zheng X. and Zhu J. 2009. Residue incorporation and $N$ fertilization affect the response of soil nematodes to the elevated $\mathrm{CO} 2$ in a Chinese wheat field. Soil Biology and Biochemistry. 41, 1497-1503.

Lobell D.B., Schlenker W. and Costa-Roberts J. 2011. Climate trends and global crop production since 1980. Science. 313, 616620.

Lorenz K., Lal R., Preston C.M. and Nierop K.G. 2007. Strengthening the soil organic carbon pool by increasing contributions from recalcitrant aliphatic bio (macro) molecules. Geoderma. 142, 1-10.

Manivannan P., Jaleel C.A., Somasundaram R., and Panneerselvam R. 2008. Osmoregulation 
and antioxidant metabolism in drought-stressed Helianthus annuus under triadimefon drenching. Comptes Rendus Biologies. 331, 418-425.

Maria A.M., G.A.A., Selim A.H. and Abd El-All A. M. 2008. Response of wheat plants grown under water stress in relation to jasmonic acid. Minufiya J. Agric. 33, 1355-1375.

Marris E. 2006. Putting the carbon back: Black is the new green. Nature Publishing Group. 442, 624-626.

Mishra A.K., and Singh V.P. 2010. A review of drought concepts. Journal of Hydrology. 391, 202-216.

Olmo M., Alburquerque J.A., Barrón V., Del Campillo M.C., Gallardo A., Fuentes M., and Villar R. 2014. Wheat growth and yield responses to biochar addition under Mediterranean climate conditions. Biology and Fertility of Soils. 50, 1177-1187.

Paneque M., José M., Franco-Navarro J. D., Colmenero-Flores J.M. and Knicker H. 2016. Effect of biochar amendment on morphology, productivity and water relations of sunflower plants under non-irrigation conditions. Catena. 147, 280-287.

Pfeiffer W.H., T.R.M., Van-Ginkel M. 2005. Breeding for abiotic stress tolerance in wheat. In: Ashraf M., Harris P.J.C. (ed): Abiotic Stress: Plant Resistance through Breeding and Molecular Approaches. The Haworth Press, Inc. NY, USA, pp. 401-489.

Piao S., Ciais P., Huang Y., Shen Z., Peng S., Li J., Zhou L., Liu H., Ma Y. and Ding Y. 2010. The impacts of climate change on water resources and agriculture in China. Nature. 467, 43-51.

Richards RA., Condon AG. and Rebetzke GJ. 2001. "Traits to improve yield in dry environments. In: Reynolds MP and OrtizMonasterio Jl. Application of physiology in wheat breeding. Centro Internacional de Nejormamiento de Maíý Trigo, Mexico DF, pp. 88-100.

Schulz H., and Glaser B. 2012. Effects of biochar compared to organic and inorganic fertilizers on soil quality and plant growth in a greenhouse experiment. Journal of Plant Nutrition and Soil Science. 175, 410-422.
Silva M.P., Moyano E.L. and Scopel A.L. 2017. Potential applications of biochar and terpeneenriched bio-oil produced from a semi-arid native Asteraceae. Journal of Analytical and Applied Pyrolysis. 126, 39-49.

Skovmand B., Reynolds M. and Delacy I. 2001. Mining wheat germplasm collections for yield enhancing traits. Wheat in a Global Environment, pp. 761-771.

Solaiman Z.M., Blackwell P., Abbott L.K. and Storer P. 2010. Direct and residual effect of biochar application on mycorrhizal root colonisation, growth and nutrition of wheat. Soil Research. 48, 546-554.

SPSS16 2002. SPSS base application guide. SPSS Inc. Chicago,USA.

Stavi I., and Lal R. 2013. Agroforestry and biochar to offset climate change: a review. Agronomy for Sustainable Development. 33, 81-96.

Yamato M., Okimori Y., Wibowo I.F., Anshori S. and Ogawa M. 2006. Effects of the application of charred bark of Acacia mangium on the yield of maize, cowpea and peanut, and soil chemical properties in South Sumatra, Indonesia. Soil Science and Plant Nutrition. 52, 489-495.

Zhang X., Jiang D., Zheng C., Dai T. and Cao W. 2011. Post-anthesis salt and combination of salt and waterlogging affect distributions of sugars, amino acids, $\mathrm{Na}+$ and $\mathrm{K}+$ in wheat. Journal of Agronomy and Crop Science. 197, 31-39.

Zhao X., Wang J., Wang S. and Xing G. 2014. Successive straw biochar application as a strategy to sequester carbon and improve fertility: A pot experiment with two rice/wheat rotations in paddy soil. Plant and Soil. $\mathbf{3 7 8 ,}$ 279-294.

Zinta G., AbdElgawad H., Domagalska M.A., Vergauwen L., Knapen D., Nijs I., Janssens I.A., Beemster G.T. and Asard H. 2014. Physiological, biochemical, and genome-wide transcriptional analysis reveals that elevated CO 2 mitigates the impact of combined heat wave and drought stress in Arabidopsis thaliana at multiple organizational levels. Global Change Biology. 20, 3670-3685. 